\title{
Ratio Data Type
}

National Cancer Institute

\section{Source}

National Cancer Institute. Ratio Data Type. NCI Thesaurus. Code C95825.

A data type comprised of a numerator quantity divided by a denominator quantity. 